\title{
Production Accuracy of English and Korean Consonant and Vowel Categories in 3-year-old Simultaneous Korean-English Bilingual Children in the U.S.
}

\author{
Sue Ann S. Lee \\ Speech-Language-Hearing Sciences, Texas Tech University Health Sciences Center, USA
}

Correspondence: Sue Ann S. Lee, PhD, CCC-SLP Department of Speech-Language-Hearing Sciences Texas Tech University Health Sciences Center, Lubbock, TX 79430, USA

Tel: +1-806-743-9051

Fax: +1-806-743-5674

E-mail: sueann.lee@ttuhsc.edu

Received: July 2, 2020

Revised: August 3, 2020

Accepted: August 3, 2020

This study was supported by the Eunice Kennedy Shriver National Institute of Child Health and Human Development (1R03HD061527A)
Objectives: In the United States, phonological development in bilingual children has been exclusively investigated in Indo-European languages such as Spanish-English bilinguals, while very limited research has been conducted in children who learn both Korean and English simultaneously. The purpose of this study was to examine whether Korean-English bilingual (KEB) children produced consonants and vowels similar to their monolingual English (ME) and monolingual Korean (MK) peers. In addition, English and Korean consonants and vowels were compared within KEB and between monolingual and bilingual children to examine whether production accuracy can be explained by the size and complexity of sound categories. Methods: Single word productions were collected from 24 children ( $8 \mathrm{KEB}, 8 \mathrm{MK}, 8 \mathrm{ME})$ using a picture naming task. All bilingual children who were exposed to both languages before 18 months of age were included. Accuracy (in percentage) of each consonant and vowel category produced by monolingual and bilingual children was compared. Results: The simultaneous KEB children produced consonants and vowels similar to ME children, but showed less accuracy compared to MK children. When English and Korean were compared, English stops and affricates were produced with higher accuracy than Korean counterparts by both monolingual and bilingual children. Conclusion: Phoneme production accuracy of simultaneous KEB children was affected by their language dominance. Furthermore, the size and complexity of phoneme category may play a role in phoneme accuracy; however, the effect of size and complexity on phoneme accuracy should also be understood relative to the order of speech acquisition.

Keywords: Phoneme accuracy, Size and complexity of speech category, Phonological development, Korean-English bilingual, Simultaneous bilingual
In the United States (U.S.) approximately $20 \%$ of the population 5 years old and over (i.e., 57 million persons) speak languages other than English (U.S. Bureau of the Census, 2010). Korea also has a growing number of children who are exposed to two languages. In 2007 , only $0.19 \%$ of students in Korea were from a family with diverse linguistic backgrounds while the number increased to $2.18 \%$ in 2018 (Korean statistics, 2019). English language ability has been considered important in Korea. Most Korean children start to learn English language at a young age (Kang \& Lee, 2018). Jun (2014) re- ported that $90 \%$ of preschools provided English lessons to young children in 2008. Thus, it is important to understand how young children who are exposed to two languages at a young age develop their phonological skills because professionals, such as early childhood educators and speech pathologists who work with bilingual children, should be prepared for increasing linguistic diversity in the classroom and in intervention settings.

Although there is a growing body of research on bilingual children's phonological acquisition in the U.S., the majority of these 
developmental studies have focused on Spanish-English bilinguals. Limited information on phonological development is available on bilingual children learning other languages simultaneously with English. The Korean language is spoken by approximately 75 million people across the world as their first language (Kim \& Pae, 2007). As one of the fastest growing languages in the U.S., over 1.7 million people speak Korean at home (U.S. Bureau of the Census, 2010). The results of the current study can improve our understanding of the nature of phonological development in bilingual children generally, as well as provide useful information to understand developmental milestones in Korean-English bilingual (KEB) children.

\section{Phonological Development in Bilingual Children}

Study of Spanish-English bilingual (SEB) learners provide a background for consideration of developmental characteristics in Korean-English bilinguals. Gildersleeve-Neumann, Kester, Davis, and Peña (2008) examined English consonant and vowel production in two groups of 33 3-year-old SEB children. The SEB participants who were equally exposed to both languages produced more English errors than SEB participants who had more previous exposure to English. However, both groups of SEB children produced more English errors than the monolingual English group, particularly consonants. When participants were reevaluated eight months later, all groups decreased in error rates. The authors concluded that duration of exposure to English may affect error rates, but similar developmental changes across the three groups suggest that all children will reach an adult-like system in English within a longer developmental time frame.

Gildersleeve-Neumann, Peña, Davis, and Kester (2009) also evaluated Spanish consonants and vowels in six 3-to-4-year-old sequential SEB children who participated in their earlier study (Gildersleeve-Neumann et al., 2008). Three children produced all Spanish consonant and vowel phonemes whereas the other three children missed only one phoneme (/r/ or /n/). These six children showed significantly increased consonant cluster accuracy. However, overall Spanish consonant production accuracy had dropped from $78 \%$ to $75 \%$ after eight months. Similar to consonants, vowel accuracy also decreased from $93 \%$ to $87 \%$. The authors argued that such negative transfer may occur because reorganization of the existing system (i.e., Spanish) is due to effects stemming from the complexity of the second language (i.e., English).

While Gildersleeve-Neumann and colleagues reported lower accuracy of speech production in Spanish-English bilingual children as compared to monolingual children, other groups of researchers reported different findings. Goldstein and Washington (2001) examined the English and Spanish phonological systems of 12 4-year-old SEB children. They found no significant differences in consonant production patterns between the two languages, arguing that bilingual participants showed similar developmental patterns to monolingual children. The children showed high consonant and vowel accuracy, although fricatives and affricates in English and the flap and trill in Spanish were not mastered by all children by the age of 4 .

Fabiano-Smith and colleagues (Fabiano-Smith \& Barlow, 2010; Fabiano-Smith \& Goldstein, 2010a) compared eight 3-year-old SEB children with monolingual peers (eight monolingual English and eight monolingual Spanish). They reported that most bilingual children demonstrated phonetic inventories at the highest levels of complexity, similar to their monolingual peers. However, their monolingual Spanish (MS) participants produced consonants with higher accuracy overall than bilingual participants. The MS children produced trills, fricatives, and glides more accurately than their bilingual peers whereas no overall difference was found in English consonant production between monolingual (ME) and bilingual (SEB) participants.

Besides SEB children, a few studies examining non-SpanishEnglish bilinguals, including Korean-English bilingual (KEB) children, have been conducted (e.g., Ha, Johnson, \& Kuehn, 2009; Kim, Ballard, \& McCann, 2017). Ha et al. (2009)'s study examined only 3 children who had learned English as a second language. A recent study (Kim et al., 2017) included $52 \mathrm{KEB}$ children ages 3;0 to 7;11 who resided in New Zealand. Twelve children in the cohort were between 3;0 and 3;11. These children were exposed to Korean from birth, but their exposure to the English language varied greatly. Their data were compared to participant data obtained from monolingual English (Dodd, Holm, Zhu, \& Crosbie, 2003) and Koreanlearning (Kim \& Pae, 2005) children. Kim et al. found that the average Percent of Consonant Correct (PCC) of both English and Korean learners in KEB children was lower than monolingual 
English and Korean children, especially in the younger age groups ( 3 to 6 years of age). Eighteen percent of the younger age group in Kim et al. (2017)'s study was one standard deviation below age matched monolingual English- and Korean-speaking participants. None of the KEB participants showed English or Korean phonological abilities above their monolingual counterparts, implying a delayed development when they were exposed to both English and Korean. The authors suggested that PCC in KEB children was comparable to monolingual children after six years of age.

Kim et al. (2017)'s results were similar to Gildersleeve-Neumann and colleagues' findings in that bilingual children's phoneme accuracy was lower than their monolingual counterparts. However, Kim et al.'s findings should be verified in further studies. Their findings may be due to their data analysis method which compared their data with existing studies descriptively. In addition, their participants showed heterogeneity in the onset of bilingualism. For example, four out of twelve 3-year-old KEB children in Kim et al.'s study were exposed to English for only a short period of time ranging from one to four months. Thus, further studies are warranted to evaluate KEB children in other English-speaking countries especially those who are exposed to both English and Korean for a substantial amount of time.

Besides KEB, Holm and Dodd (1999)'s initial report on two Cantonese-English bilingual children suggested that their participants demonstrated unusual error patterns in English such as aspiration and backing. In addition, Lin and Johnson (2010) analyzed data on 25 4- to 5-year-old Mandarin-English-learning bilingual children. They reported greater than 90\% accuracy for English consonant and vowel productions although these participants were exposed to English for only one-and-a-half years. Only two vowel phonemes were produced incorrectly. These errors were cited as evidence of Mandarin influence on English (e.g., [banana] or [vekjum]).

In summary, due to the limited information on phonological acquisition in bilingual children, especially children from language pairs other than Spanish-English, understanding the nature of phonological development in bilingual children is still incomplete. In particular, a few studies have been conducted to examine phonological development in Korean-English bilingual children. Thus, further studies are warranted to investigate whether Korean-Eng- lish bilingual children's English and Korean phonological skills are as delayed as monolingual children.

\section{The effect of size and complexity of phoneme category on production accuracy}

In addition to investigating phonological characteristics in bilingual children compared to monolingual children, another important question in bilingual research is to explain why and how bilingual children demonstrate their unique patterns of phonological acquisition. The dominant theories for bilingual children's development in phonological and other language domains can be characterized by the question of whether bilingual children possess a unitary or a dual system for their languages (Genesse, 1989; Volterra \& Taeschner, 1978) or what types of cross-linguistic interaction (i.e., acceleration, delay, and transfer) between their two languages are manifested (Paradis \& Genesee, 1996). These questions mainly focus on explaining the nature of the underlying linguistic system and its interaction in bilingual children (i.e., how). However, it is still not certain why certain linguistic patterns appear in bilingual children in these theoretical models. Thus, further studies are warranted to examine possible overall and language-specific factors which may affect phonological developmental patterns in bilingual children.

An aspect to be considered in phonological development is phoneme inventory size, which refers to the number of phonemes in a language. The concept of phoneme inventory size has been used to examine relationships between inventory size and word length (Nettle, 1995) and speech production (Flege, 1989). Relative to speech production patterns, Flege hypothesized that native speakers of English will maximize the articulatory distance between vowels by using more extreme tongue positions than native speakers of Spanish when they produce the common vowels in the two languages based on Lindblom's Theory of Adaptive Dispersion (Lindblom, 1983). Flege found that English-speaking adults produced the five corner vowels $(/ \mathrm{i}, \mathrm{u}, \mathrm{a}, \mathrm{e}, \mathrm{o} /)$ with a greater range of vertical tongue positions than Spanish speakers. Spanish has a smaller vowel inventory size (5 vowels) than English (11 vowels). Flege claimed that vowel inventory size might affect the location of tongue position in vowel phonemes in a language.

Lindblom and Maddieson (1988) also used the concept of inven- 
tory size to explain patterns of consonants in world languages. They further categorized consonants into three classes in terms of complexity of articulatory gestures. Set I consist of consonants with basic articulations; Set II is composed of consonants with elaborated articulations that are produced with advanced place, voicing and manner features such as breathy, creaky, and ejective; Set III includes consonants with combinations of elaborated articulations. In other words, they are produced with more than two features of Set II such as a uvular stop with labialization. Table 1 shows the proposed English and Korean consonant complexity based on the inventory size and Lindblom and Maddieson (1988)'s classification. In the current study, the inventory size is defined as the number of phonemes in each category of the phoneme inventory in a given language. Korean stops and affricates are considered more elaborated articulations than English phonemes because Korean lenis and fortis can be considered producing beyond the 'default' mode of phonation in addition to the fact that the number of stops and affricates is larger in Korean than in English. On the other hand, English fricatives are produced with more elaborated articulations than Korean in that English has a relatively larger number of fricatives including voiced fricatives whereas Korean has only three voiceless fricatives (i.e., /s, s', h/). Voiced fricatives are classified as Set II according to Lindblom and Maddieson. Furthermore, the place features of Set II are composed of sounds that are produced with beyond the near-rest positions of tongue-body components (i.e., retroflex; Lindblom \& Sundberg, 1971). Thus, English liquid /r/, which is a retroflex, can be classified as Set II while Korean liquid, which presumably is produced as a flap [r] syllable-initially or as [1] syllable-finally (Ladefoged \& Maddieson, 1996) can be categorized as Set I. Neither language has consonants that are classified as Set III. With respect to vowels, similar to Flege (1989), the current paper considered English to have a more complex vowel

Table 1. Proposed consonant complexity based on inventory size and Lindblom and Maddieson (1988)' classification

\begin{tabular}{lllc}
\hline & \multicolumn{1}{c}{ Set I } & \multicolumn{1}{c}{ Set II } & Set III \\
\hline English & $\begin{array}{c}\text { Stop (6), Affricate (2), Nasal (3), } \\
\text { Glide (2) }\end{array}$ & Fricative (9), Liquid (2) & NA \\
Korean & $\begin{array}{l}\text { Fricative (3), Nasal (3), Glide (2), } \\
\text { Liquid (1) }\end{array}$ & Stop (9), Affricate (3) & NA \\
\hline
\end{tabular}

The numbers in parenthesis indicate the number of phonemes in a consonant category. system than Korean not only because the total number of vowels is larger in English (11) than in Korea (7) but also because most vowel categories (e.g., high-front vowel) consist of more vowels in Eng$\operatorname{lish}(/ \mathrm{i}, \mathrm{I} /)$, than in Korean (/i/).

One relevant question raised here is how inventory size and complexity of phoneme category may influence production accuracy in bilingual-learning children. In other words, when a language is composed of stops appearing in Set II (i.e., elaborated), children who acquire the language may demonstrate more difficulty in producing stops than children whose stop inventory is limited to Set I (i.e., basic). The current study was designed to answer this question in terms of KEB children.

\section{Phonological development in monolingual English- speaking and Korean children}

Since the current study compares KEB children with monolingual counterparts, it is necessary to briefly discuss consonant and vowel accuracy in ME and MK children. Using single words, English-speaking children aged from 3;0 to 3;5 produced English consonants and vowels with 93\% and 97\% accuracy, respectively (Pollock, 2002; Pollock \& Berni, 2003). Stops, nasals, and glides were produced with $75 \%$ accuracy by age 3 . Glottal (/h/) and labiodental (/f, v/) fricatives were developed earlier (by age 3) than other fricatives. Alveolar $(/ \mathrm{s}, \mathrm{z} /)$ and palate $\left(/ \int, 3 /\right)$ fricatives as well as affricates $(/ \mathrm{t} \mathrm{f}, \mathrm{b} /)$ reached $75 \%$ accuracy by age 4 . Finally, interdental fricatives $(/ \theta$, ð/) and retroflex $(/ \mathrm{r} /)$ were produced with $75 \%$ accuracy by age 5 (Arlt \& Goodban, 1976). These late developing English consonants were produced with $90 \%$ accuracy between age 7 and 9 (Smit, Hand, Freilinger, Bernthal, \& Bird, 1990). Unlike consonants, monophthongal vowels were produced with $99 \%$ or higher accuracy by 38 months of age (Larkins, 1983).

In terms of Korean, Kim and Pae (2005) reported that by around 3 years of age, Korean children have acquired all consonants except for the liquid /1/ and alveolar fricatives $\left(/ s, s^{\star} /\right)$. These sounds were not acquired fully until 5 or 6 years of age. However, the acquisition of the liquid /1/ varied depending on word position. While the syllable-initial /1/ is acquired by 5 years, the syllable-final position is acquired by 3 years. Similar to English, Korean vowels are acquired by the age of 3 (Kwon, 1982). Korean diphthongs combined with /j/ are also acquired before the age of 3 although diph- 
thongs combined with /w/ are acquired by the age of 5 .

\section{The purpose of the current study}

The present study had two goals. The first goal was to examine whether consonant and vowel phoneme production accuracy in KEB children is significantly different from monolingual counterparts. The second goal was to examine whether production accuracy in monolingual and bilingual children is influenced by phoneme inventory size and complexity of consonant and vowel categories. The results of the current study will improve our understanding of phonological acquisition patterns in KEB children and make a contribution to the current body of literature by proposing a new perspective to view how phonological patterns emerge in monolingual and bilingual children.

\section{METHODS}

\section{Participants}

Twenty-four typically developing children without any speech or hearing problems, whose ages ranged from 3;1 (year; month) to $3 ; 6$, participated. There were three groups of 8 children each: Korean-English early bilingual children (KEB), monolingual Englishspeaking (ME), and monolingual Korean-speaking (MK) children. The ME ( $\mathrm{M}$ age $=3 ; 4)$ and $\mathrm{MK}$ children $(\mathrm{M}$ age $=3 ; 3)$ were from monolingual English-speaking families in Texas in the U.S. or monolingual Korean-speaking families in the Seoul metropolitan area in South Korea in which Southwestern American English or standard Korean (Seoul dialect) was spoken, respectively.

Eight KEB ( $M$ age = 3;3) children were also recruited in Texas. Bilingual children are commonly categorized into simultaneous and sequential. Simultaneous bilinguals are those who learn two languages from birth (Padilla \& Hindholm, 1984) or who have acquired the second language (L2) before the first language (L1) is established (Hamers \& Blanc, 2000). On the other hand, sequential bilingual children are those who begin to have exposure to the L2 later in childhood or adulthood (Goldstein, 2004). The participating KEB children were classified as simultaneous because either they learned two languages from birth or they started to learn English before the Korean language was established.

All KEB children in the current study were raised by bilingual parents who use both English and Korean on a daily basis, with the exception of two children. The fathers of these two children were native English speakers who do not know Korean. During the parent interview, it was found that for these two KEB participants, mothers typically spoke Korean while fathers spoke only English to their child from birth. For the other six children, Korean was the main language spoken to the children until they started to attend English-speaking daycare centers (Table 2). The ages of attending the English-speaking daycare centers varied among the six children, from six months to 1 year and 6 months. Since they attended English-speaking daycare centers, either parent, typically mothers, spoke English to the child at home to help develop English skills; however, both parents used both languages when communicating with their children.

In order to objectively evaluate the participating child's English language skills, the Preschool Language Scale 4-Screening Test (PLS-4 Screening; Zimmerman, Steiner, \& Pond, 2005) was conducted and all children passed the screening testing. For Korean, parents were asked to answer the Communication section of the Korean Age and Stage Questionnaire (K-ASQ; Heo, Squires, Lee, \& Lee, 2006). The Korean language system was found to be developing within typical expectations for their chronological age. In addition, a short conversation between mother and child in both English and Korean was recorded to evaluate the child's English and Korean language skills. The recordings were listened to by a native English or a native Korean speaker who was blind to the study. Each child's proficiency was rated for each language on a scale from 0 (child could not speak the indicated language at all) to

Table 2. Participants' Characteristics

\begin{tabular}{lccccc}
\hline Child ID & Age & Sex & $\begin{array}{c}\text { Age of attending Eng- } \\
\text { lish-speaking daycare }\end{array}$ & $\begin{array}{c}\text { English } \\
\text { proficiency }\end{array}$ & $\begin{array}{c}\text { Korean } \\
\text { proficiency }\end{array}$ \\
\hline KEB1 & $3 ; 4$ & M & $1 ; 6$ & 4 & 3 \\
KEB2 & $3 ; 2$ & F & $0 ; 6$ & 4 & 4 \\
KEB3 & $3 ; 5$ & F & $1 ; 6$ & 4 & 3 \\
KEB4 & $3 ; 2$ & F & Birth & 4 & 4 \\
KEB5 & $3 ; 5$ & M & $1 ; 6$ & 4 & 3 \\
KEB6 & $3 ; 1$ & M & $1 ; 0$ & 4 & 4 \\
KEB7 & $3 ; 4$ & M & $1 ; 0$ & 4 & 4 \\
KEB8 & $3 ; 3$ & F & Birth & 4 & 4 \\
\hline
\end{tabular}

KEB 4 \& 8 were exposed to the English language from birth because one parent only spoke English to the child. 
4 (child had native-like proficiency in the language). These scales have been used in previous bilingual studies (Fabiano-Smith \& Goldstein, 2010a, 2010b; Bedore, Peña, Joyner, \& Macken, 2011). Based on the recorded conversations and parent interview, all of the bilingual children were rated by the two evaluators as either 3 or 4 in both Korean and English. Half of the KEB children were balanced bilinguals while the other half of the children were slightly English-dominant.

\section{Data Collection}

The monolingual and bilingual data were collected at daycare centers or in participants' homes in a quiet room. The GoldmanFristoe Test of Articulation-2 (GFTA-2; Goldman \& Fristoe, 2000) and the Assessment of Phonology and Articulation for Children (APAC; Kim, Pae, \& Park, 2007) were used to elicit English and Korean phonemes within single words, respectively. A digital flash recorder (Marantz Model PMD670) and a wireless microphone (Sennheizer Model EW100) were used to audio-record. Each child wore a wireless microphone clipped to their clothing at the shoulder. A Korean-English bilingual researcher collected all Korean and English data from the bilingual children. When English words were being elicited, conversation with the experimenter was in English only, and when Korean words were elicited, all conversation was in Korean.

\section{Transcriptions \& Reliability}

Word productions were transcribed using the International Phonetic Alphabet (IPA) with broad transcription conventions by a native English or Korean speaker blind to study goals. The transcribers were graduate students who majored in either Speech-Language Pathology or Linguistics. To support more accurate transcription, a waveform editor was used so that each word production could be played as often as necessary. In addition, spectrograms and spectra were generated when segments were not perceptually apparent. To obtain reliability, another set of native English- or Korean-speaking students who were blind to study goals re-transcribed a randomly selected $10 \%$ of data and reliability was reported using percent agreement and Cohen's Kappa between the two raters. Cohen's Kappa is a commonly used quantitative measure of inter-rater reliability in speech analysis and considered a more robust measure than percent agreement (McHugh, 2012). The strength of agreement of Cohen's Kappa statistics are interpreted as slight (0.0-0.2), fair (0.2-0.4), moderate (0.4-0.6), substantial (0.6-0.8), and almost perfect (0.8-1.0).

For evaluating inter-rater reliability, 152 English consonants and vowels and 154 Korean consonants and vowels were re-transcribed. The percent agreement for ME and MK groups were $95.3 \%$ and $94.1 \%$, respectively. The reliability, in terms of percent agreement, for KEB children' English and Korean phoneme productions were $91.4 \%$ and $93.5 \%$ respectively. The reliability coefficients (Cohen's Kappa, $K$ ) indicate almost perfect agreement between the two raters for all comparisons $(K=.95$ for $\mathrm{ME}, K=.92$ for $\mathrm{MK}$, $K=.89$ for KEB English, and $K=.92$ for KEB Korean).

\section{Data Analysis}

The transcribed data were entered into a database enabling computer analysis (Logical International Phonetic Program, LIPP; Oller, \& Delgado, 1990) for both independent and relational analyses. Independent analysis determined the phonetic inventory of English and Korean consonants and vowels present. Relational analyses identified percentage of consonant and vowel accuracy. A relational analysis was conducted in terms of consonant manner dimensions (i.e., stop, nasal, fricative, affricate, glide, and liquid). Vowels were analyzed as high-front [i r ], mid-front [e e ], low-front [æ], high-central [i] , mid-central $\left[\begin{array}{lll}\Lambda & \gamma^{\circ} 3^{0}\end{array}\right]$, low-central [a], highback [u v], mid-back [o o], and low-back [a] dimensions. Although glides are combined with vowels to form diphthongs in Korean, the current study considered glides in Korean as consonants in order to make English and Korean comparable.

All singleton consonants and vowels within each target word were analyzed regardless of position (i.e., initial, medial or final position), resulting in a total of 109 English consonant and 79 English vowel sounds and 109 Korean consonant and 82 Korean vowel sounds per child. Tables 3 and 4 show the number of consonant and vowel sounds for each category analyzed for English and Korean. Percentage of accuracy for each consonant and vowel category was obtained by dividing the number of correct consonants or vowels per category by the total number of consonants or vowels per category multiplied by 100 . Two non-parametric statistics were employed in order to determine significance. A Wilcoxon test was 
Table 3. The number of English and Korean consonants of each category analyzed per child

\begin{tabular}{lcccccc}
\hline Consonants & Stop & Nasal & Fricative & Affricate & Liquid & Glide \\
\hline English & 30 & 24 & 30 & 5 & 14 & 6 \\
Korean & 36 & 24 & 14 & 8 & 10 & 8 \\
\hline
\end{tabular}

Table 4. The number of English and Korean vowels of each category analyzed per child

\begin{tabular}{lccccccccc}
\hline Vowels & HF & MF & LF & HC & MC & LC & HB & MB & LB \\
\hline English & 14 & 6 & 11 & & 24 & & 7 & 3 & 14 \\
Korean & 13 & 8 & & 1 & 11 & 25 & 7 & 17 &
\end{tabular}

$\mathrm{HF}=$ High-Front; $M F=$ Mid-Front; $L F=L$ Low-Front; $H C=$ High-Central; $M C=$ Mid-Central; $\mathrm{LC}=$ Low-Central; $\mathrm{HB}=$ High-Back; $\mathrm{MB}=$ Mid-Back; $\mathrm{LB}=$ Low-Back.

used for within subject group comparisons (i.e., English vs. Korean produced by KEB children). A Mann-Whitney U test was used for between group comparisons (i.e., English production between $\mathrm{ME}$ and KEB children).

\section{RESULTS}

\section{Phonetic Inventory}

In order to obtain a broader understanding of production patterns of these children, phonetic inventories of consonant and vowel phonemes in all three positions (initial, medial, and final) of words were enumerated descriptively. Since the GFTA-2 does not test the voiced palatal fricative $/ 3 /$, the sound was not included in the inventory. Tables 5 and 6 show sounds that are not included in the consonant and vowel inventory of each language in monolingual and bilingual children, respectively.

For consonants, both monolingual and bilingual participants demonstrated phonetic inventories typical for their chronological age (Kim \& Pae, 2005, 2007; Rvachew \& Brousseau-Lapre, 2012). Many of these children did not produce later-developing English consonants. Their consonant inventories lacked some fricatives (e.g., /v, S/ and affricates (e.g., / t $\mathrm{c} /$ /), particularly inter-dental fricatives $(/ \theta, \partial /)$. The rhotic / $/ \mathrm{r} /$ was also missing in some children in both ME and KEB groups. Most ME and KEB participants produced all vowel phonemes. One interesting aspect related to vowels is that the stressed schwa $/ 3^{2} /$ appeared in all KEB children, but not in ME children. Three out of eight ME did not produce $/ 3 \%$ One KEB child produced the English /e/ as / $\varepsilon /$.
Table 5. Missing sounds in English consonant and vowel inventories of monolingual English and Korean-English bilingual children

\begin{tabular}{|c|c|c|c|}
\hline Group & Child ID & Consonants & Vowels \\
\hline \multirow[t]{8}{*}{ Monolingual } & ME1 & 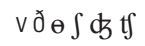 & \\
\hline & ME2 & r & $3^{n}$ \\
\hline & ME3 & $v_{\Theta}$ & \\
\hline & ME4 & $\partial \phi t$ & $3^{n}$ \\
\hline & ME5 & vðө & \\
\hline & ME6 & ð & \\
\hline & ME7 & & \\
\hline & ME8 & $\partial_{\theta} r$ & $3^{n}$ \\
\hline \multirow[t]{8}{*}{ Bilingual } & KEB1 & бळ & \\
\hline & KEB2 & ð & \\
\hline & KEB3 & $\partial_{\theta}$ & \\
\hline & KEB4 & เฮ & \\
\hline & KEB5 & ð & \\
\hline & KEB6 & vðsकr & $\mathrm{e}$ \\
\hline & KEB7 & & \\
\hline & KEB8 & $\partial_{\theta}$ & \\
\hline
\end{tabular}

Table 6. Missing sounds in Korean consonant and vowel inventories of monolingual Korean and Korean-English bilingual children

\begin{tabular}{|c|c|c|c|}
\hline Group & Child ID & Consonants & Vowels \\
\hline \multirow[t]{8}{*}{ Monolingual } & ME1 & & \\
\hline & ME2 & & \\
\hline & ME3 & & \\
\hline & ME4 & $s s^{*} t \int t t^{h}$ & \\
\hline & ME5 & $s^{*}$ & \\
\hline & ME6 & $\mathrm{s}$ & \\
\hline & ME7 & & \\
\hline & ME8 & $s^{*}$ & \\
\hline \multirow[t]{8}{*}{ Bilingual } & KEB1 & $\mathrm{t}^{*}$ & \\
\hline & KEB2 & & \\
\hline & KEB3 & $\operatorname{tg}^{h}$ & \\
\hline & KEB4 & & \\
\hline & KEB5 & & \\
\hline & KEB6 & $\mathfrak{t g}^{*}$ & \\
\hline & KEB7 & $\mathfrak{t}^{*}$ & \\
\hline & KEB8 & $\operatorname{tg} \mathfrak{t}^{*}$ & \\
\hline
\end{tabular}

Four MK and three KEB children produced all the Korean consonants. The other children lacked some consonants; but the patterns were not the same between MK and KEB children. All missing Korean consonants in KEB children were affricates, either lenis, fortis, or aspirated whereas missing Korean consonants in MK children were affricates and fricatives, either lenis or fortis. All Korean vowels appeared in both groups of children. 
Sue Ann S. Lee • Consonant and Vowel Production Accuracy in Korean-English Bilinguals

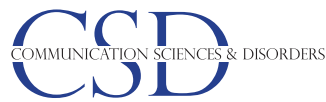

Table 7. Means and standard deviations (in Parenthesis) of production accuracy (\%) of each consonant category

\begin{tabular}{lllllll}
\hline Language groups & \multicolumn{1}{c}{ Stops } & Nasals & Fricatives & Affricates & Liquids & Glides \\
\hline Monolingual English children & $90.89(3.14)$ & $87.96(9.77)$ & $68.62(21.32)$ & $65.00(33.99)$ & $53.38(23.80)$ & $83.26(17.93)$ \\
Bilingual children (English data) & $85.39(9.37)$ & $79.90(17.50)$ & $56.06(13.75)$ & $87.01(14.39)$ & $70.81(18.53)$ & $98.61(3.92)$ \\
Monolingual Korean children & $74.19(8.48)$ & $91.67(6.29)$ & $50.85(28.27)$ & $68.06(26.85)$ & $95.83(7.71)$ & $86.94(16.56)$ \\
Bilingual children (Korean data) & $60.60(11.79)$ & $83.66(7.56)$ & $55.52(15.90)$ & $39.20(14.24)$ & $69.97(15.76)$ & $85.63(11.39)$ \\
\hline
\end{tabular}

Table 8. Means and standard deviations (in parenthesis) of production accuracy (\%) of each vowel category

\begin{tabular}{|c|c|c|c|c|c|c|c|c|c|}
\hline Language groups & $\mathrm{HF}$ & MF & LF & $\mathrm{HC}$ & MC & LC & $\mathrm{HB}$ & MB & LB \\
\hline Monolingual English children & $95.00(5.96)$ & $90.51(10.59)$ & $91.96(12.40)$ & & $77.95(11.04)$ & & $92.59(10.62)$ & $85.00(18.32)$ & $91.55(12.78)$ \\
\hline Bilingual children (English data) & $87.97(8.22)$ & $79.76(34.00)$ & $84.90(13.17)$ & & $80.70(11.58)$ & & $100(0.0)$ & $88.54(13.31)$ & $93.33(12.84)$ \\
\hline Monolingual Korean children & $99.04(2.72)$ & $100(0.0)$ & & $100(0.0)$ & $100(0.0)$ & $98.94(1.97)$ & $100(0.0)$ & $97.70(4.60)$ & \\
\hline Bilingual children (Korean data) & $93.46(8.79)$ & $90.18(11.25)$ & & 87.50 (35.35) & 74.07 (15.94) & $94.67(4.20)$ & 93.92 (9.33) & $91.43(5.18)$ & \\
\hline
\end{tabular}

HF= High-Front; MF= Mid-Front; LF=Low-Front; HC= High-Central; MC=Mid-Central; LC=Low-Central; HB=High-Back; MB=Mid-Back; LB=Low-Back.

\section{Accuracy of consonant and vowel categories}

\section{Comparisons of English production between ME and KEB} children

Overall accuracy for English consonants and vowels produced by $\mathrm{ME}$ and KEB children was similar. ME participants produced consonants and vowels with $80 \%$ and $88 \%$ accuracy. KEB children produced English consonants with $72 \%$ accuracy and vowels with $86 \%$ accuracy respectively. Tables 7 and 8 show the mean and standard deviation for production accuracy for each English consonant and vowel category in ME and KEB children. Mann-Whitney $U$ tests indicated no significant differences in English consonant and vowel accuracy between ME and KEB children for any category analyzed. KEB children produced English consonants similarly to ME children $(z=-1.26, p=.21$ for stops, $z=-.84, p=.40$ for nasals, $z=-1.89, p=.06$ for fricatives, $z=1.54, p=.12$ for affricates, $z=-.28, p=.78$ for glides, $z=-.152, p=.13$ for liquids) and vowels $(z=1.71, p=.09$ for high-front, $z=-.23, p=.84$ for mid-front, $z=-1.42, p=.15$ for low-front, $z=-.82, p=.41$ for mid-central, $z=$ -1.74, $p=.08$ for high-back, $z=-.11, p=.92$ for mid-back, $z=-.30$, $p=.77$ for low-back).

\section{Comparisons of Korean production between MK and KEB} children

Overall accuracy for Korean consonants and vowels produced by $\mathrm{MK}$ and KEB children was different. While MK children produced consonants and vowels with $76 \%$ and $98 \%$ accuracy respectively, KEB children produced consonants with $63 \%$ and vowels
Table 9. Means and standard deviations (in parenthesis) of production accuracy $(\%)$ of three-way Korean voicing contrast

\begin{tabular}{lccc}
\hline & Lenis & Fortis & Aspirated \\
\hline Monolingual & $51.56(13.17)$ & $82.29(15.70)$ & $87.50(25.87)$ \\
Bilingual & $39.50(10.14)$ & $75.32(18.10)$ & $71.53(19.57)$ \\
\hline
\end{tabular}

with $89 \%$ accuracy respectively. Tables 7 and 8 show the mean and standard deviation for each Korean consonant and vowel category produced by MK and KEB children. Mann-Whitney $U$ tests indicated MK children produced Korean stops, nasals, affricates, and liquids with significantly higher accuracy than $\operatorname{KEB}$ children $(z=$ -2.31, $p=.02$ for stops, $z=-2.01, p=.04$ for nasals, $z=-2.53, p=.01$ for affricates, $z=-2.59, p=.009$ for liquids). The rest of the consonant categories such as fricatives and glides did not differ significantly in accuracy between the two groups $(z=-.64, p=.52$ for fricatives, $z=-.05, p=.96$ for glides).

Since Korean possesses a three-way laryngeal system for obstruents in contrast with the two-way contrast in English, we further examined potential differences in accuracy for the three-way laryngeal contrast. Means and standard deviations are shown in Table 9. MK children produced lenis phonemes with significantly higher accuracy than KEB children $(z=-2.10, p=.03)$. However, no significant differences were found in the other two phonation types between MK and KEB groups $(z=-.85, p=.40$ for fortis, $z=$ $-1.72, p=.08$ for aspirated).

Although both MK and KEB participants produced Korean vowels with high accuracy (Table 8 ), their vowel productions were 
statistically different. MK children produced most vowel categories with higher accuracy than $\mathrm{KEB}$ children $(z=-2.21, p=.03$ for mid-front, $z=-3.42, p=.001$ for high-central, $z=-3.59, p=.001$ for mid-central, $z=-2.04, p=.042$ for low-central, $z=-2.30, p=.02$ for mid-back). Only high front $(z=-1.59, p=.11)$ and high-back vowels $(z=-1.84, p=.06)$ were not significantly different between MK and KEB children.

\section{Comparisons between English and Korean phonemes in}

\section{KEB children}

Overall accuracies produced by KEB participants were $72 \%$ for English consonants and 86\% for vowels. They produced Korean consonants and vowels with $63 \%$ and $89 \%$ accuracy respectively. Wilcoxon tests were performed to examine if English and Korean consonants were produced with different accuracy. The KEB children produced English stops $(z=-2.52, p=.01)$, affricates $(z=-2.52$, $p=.01)$, and glides $(z=-2.21, p=.02)$ with significantly higher accuracy than Korean phonemes. Production accuracy for nasals, fricatives, and liquids were not significantly different between English and Korean $(z=-.70, p=.48$ for nasals, $z=-.28, p=.78$ for fricatives, $z=-.14, p=.89$ for liquids).

KEB children produced English and Korean vowels with similar levels of accuracy. Wilcoxon tests indicated that there were no significant differences between English and Korean for any vowel categories $(z=-1.68, p=.09$ for high-front, $z=-.32, p=.75$ for midfront, $z=-.34, p=.74$ for mid-central, $z=-1.60, p=.11$ for high-back, $z=-.94, p=.34$ for mid-back, $z=-.17, p=.86$ for low central-low back).

\section{Comparisons between English and Korean phonemes in ME} and MK children

Overall accuracy for consonants and vowels was relatively high in both monolingual groups. MK children produced consonants and vowels with $76 \%$ and $98 \%$ accuracy, respectively. ME children produced consonants with $80 \%$ accuracy and vowels with $88 \%$ accuracy. MK children showed higher accuracy for vowels whereas ME children were more accurate for consonants.

In order to determine if consonant accuracy percentages differed in the two groups, multiple Mann-Whitney $U$ tests were performed. Results indicated that ME children produced stops with signifi- cantly higher accuracy than MK children $(z=-3.36, p=.001)$. MK children produced liquids with significantly higher accuracy $(z=$ $-3.02, p=.002)$. For the other manner categories, there were no significant differences in accuracy between the two groups $(z=-.53$, $p=.60$ for nasals, $z=-1.47, p=.14$ for fricatives, $z=.00, p=1.0$ for affricate, $z=-.53, p=.96$ for glide).

Mann-Whitney $U$ tests were also conducted for high-front, midfront, mid-central, high-back, mid-back categories to consider differences in accuracy. Comparisons for low-front and high-central categories were not made because only one language has such vowels. English /a/ and Korean /a/ were compared although they were in different categories. Accuracy for mid-front and mid-central vowel categories differed between $\mathrm{ME}$ and MK children $(z=-2.40$, $p=.01$ for mid-front; $z=-3.34, p=.001$ for mid-central). MK children produced the vowels with higher accuracy than ME children. Vowel accuracy for other categories was not significantly different ( $z=-1.08, p=.72$ for high-front, $z=-1.74, p=.08$ for high-back, $z=-1.24, p=.21$ for mid-back, $z=-.72, p=.48$ for low central-low back).

\section{DISCUSSION}

This study had two goals. The primary goal was to examine whether phoneme accuracy in 3-year-old KEB children who had been exposed to both English and Korean at an early age was significantly different from their monolingual counterparts. The second goal was to examine whether children's production accuracy can be explained by the size and complexity of sound category.

In terms of the first goal, we found that these KEB children showed similar phoneme production accuracy compared to ME children whereas their Korean phoneme accuracy was lower than MK children for most consonant and vowel categories. Such results were consistent with the initial observation in that the English language skills of all bilingual children were rated relatively high (i.e., 4) whereas Korean language skills of some of these bilingual children were rated as 3 .

Our findings on English accuracy were similar to findings in some previous studies of bilinguals (i.e., Fabiano-Smith \& Goldstein, 2010a; Goldstein \& Washington, 2001; Holm \& Dodd, 1999) in that English accuracy of the Spanish-English or Chinese-Eng- 
lish bilingual children was similar to ME children. However, our findings were different from Gildersleeve-Neumann et al. (2008)'s study of Spanish-English bilinguals. Gildersleeve-Neumann and colleagues reported that English-dominant and balanced SEB children demonstrated lower English accuracy compared to monolingual English-speaking children (i.e., English only). It is not clear why the bilingual and English dominant bilingual children in their study demonstrated lower English phoneme accuracy than monolingual English participants. The different findings may be because Gildersleeve-Neumann et al. recruited their participants based on a vocabulary and intelligence test without testing overall language abilities and/or considering parents' input or the onset of English exposure. Thus, the children in their three groups might not have had similar English language abilities to ME children.

The finding of the current study was also different from one recent KEB study (Kim et al., 2017). Kim et al. reported that 3-yearold KEB's English phoneme production skills were lower than age equivalent ME children. English phoneme skills of KEB children were comparable with ME beyond 6 years of age. Most KEB children in Kim et al.'s study was exposed to English for a short period. For example, four out of the twelve 3-year-old KEB children in their study were exposed to English for only three months on average, indicating that these four children may have developed very limited English abilities. Among the 12 participants, ten were exposed to Korean much more frequently than English on a daily basis. Thus, most KEB children in their study were raised in a family where Korean language usage was dominant. Only two children (whose father was a native English speaker) experienced a similar amount of exposure to both languages. Unlike Kim et al., all participants in the current study were exposed to both languages by 18 months of age or earlier. Furthermore, all KEB children received balanced language input from both languages in that they were attending an English-speaking daycare center or one of their parents was a native English speaker. Thus, our finding along with Kim et al.'s results suggest that English phoneme accuracy in 3-yearold KEB children may be heavily determined by exposure duration to the English language. Thus, researchers should carefully evaluate KEB phoneme production skills with respect to their participants' language experience. Although more studies are warranted to verify our findings, it seems that more evidence is emerg- ing that bilingual children demonstrate similar English production skills to monolingual English-speaking children when they are exposed to English at an early age.

Unlike English, KEB children produced Korean consonants and vowels with a lower accuracy level. Our findings on Korean phoneme patterns in production were also similar to Fabiano-Smith and Goldstein (2010a). Their SEB participants produced Spanish consonants with lower accuracy than monolingual Spanish-learning children. In particular, their bilingual participants produced trills, fricatives, and glides less accurately than their monolingual Spanish learning peers. Trills and fricatives are later developing sounds in Spanish (Fabiano-Smith \& Goldstein, 2010b). In the current study, KEB children produced stops and affricates, in particular lenis, with lower accuracy than MK participants. Lenis stops are acquired later than Korean fortis and aspirated stops (Kim \& Stoel-Gammon, 2009). Lenis stops are also acquired later than other consonants (Kim \& Pae, 2005). Thus, late-developing sounds may be phonemes that bilingual children produce with more errors than monolingual children. In summary, KEB children who were either balanced or English dominant produced English phonemes more accurately than Korean phonemes. Lower accuracy was especially observed in the late developing phonemes in Korean in bilingual children.

Another goal of the current study was to compare English and Korean productions of KEB children to consider whether their production patterns could be understood by the size and complexity of sound category. Although the current theories of bilingual acquisition made attempts to explain how bilingual individuals develop a phonological system of each language, why such patterns are observed has not been fully answered. In addition to bilingual children, we compared ME and MK children as well to evaluate if there are similar production patterns observed in monolingual children. The primary finding of the study was that Korean stops were produced less accurately than English stops in both bilingual and monolingual groups. Korean affricates were also produced less accurately than English affricates by KEB children. Why was production accuracy lower in Korean stop and affricate categories? Recall that Korean stop and affricate consonant categories have a larger phoneme size (i.e., a three-way compared to a twoway English contrast) and their complexity is considered as Set II 
(elaborated consonants) following Lindblom and Maddieson (1988)'s classification. Thus, although there was no difference in affricate production between ME and MK children, these findings suggest that size as well as the complexity of sound category may be associated with production accuracy.

The effect of inventory size and the complexity of articulatory gestures in sound category was also found in other phonemes in monolingual English and Korean learning participants. MK participants produced liquids and mid-central vowels with higher accuracy than ME participants. KEB participants also produced Korean liquids with higher accuracy than English liquids. The English liquid category is composed of two phonemes, /r/ and /1/ while Korean has only one liquid phoneme. In addition, the English $/ \mathrm{r} /$ is considered Set II due to the retroflex of tongue configuration. Furthermore, the English mid-central vowel category is composed of four phonemes (i.e., $/ \curvearrowright \wedge 3^{u} \gamma^{r} /$ ) while Korean has only one (i.e., $/ \Lambda /$ ) phoneme. Production accuracy with the r-colored or rhotic vowel may affect overall accuracy for the mid-central vowels of English.

While our findings on stop and affricate consonants were consistent with our prediction, findings for fricatives were not. One may ask why ME, MK, and KEB children produced fricatives similarly given that English has a larger inventory size for fricatives that involve more complex articulatory gestures than Korean. This finding may suggest that the effect of size and complexity of sound category on production accuracy should be understood relative to the order of sound acquisition. Fricatives are late-developing sounds in most languages (McLeod, 2007). In both English and Korean children, fricatives are also later developing (Bernthal, Bankson, \& Flipsen, 2009; Kim \& Pae, 2007). Thus, the statistical similarities of fricative production accuracy in these ME, MK, and KEB children may be attributed to their challenges for children's production system leading to later development across languages. As a result, fricative developmental profiles may be a difficult phoneme type to evaluate differences in acquisition of accuracy between monolingual and bilingual learners in languages. Similarly, although English vowels are more complex than Korean (e.g., two vowels in high-front, mid-front, high-back, and mid-back categories of English whereas there is only one vowel in the same categories of Korean), vowels are typically acquired by 3 years of age in both English (Larkins, 1983; Otomo \& Stoel-Gammon, 1992) and
Korean (Kwon, 1982). The inventory size may not affect the production accuracy greatly in this category.

\section{CONCLUSIONS \& LIMITATIONS}

In summary, this study found that KEB children who were exposed to both Korean and English simultaneously produced dominant language phonemes (i.e., English) more accurately than less dominant language phonemes (i.e., Korean). Lower accuracy was especially observed in the late developing phonemes (e.g., lenis stops) in the less dominant language in bilingual children. Furthermore, production accuracy of sound category with a larger size and higher complexity (e.g., stops, affricates, and liquids) was lower than that of sound category with a smaller size and less complexity. When evaluating phonological acquisition in bilingual children, previous studies have mainly reported phoneme accuracy. To our knowledge, only a few studies have attempted to identify a factor that explains the unique production patterns observed in these children. Although further studies are warranted to confirm the findings of the current study, this study claims that the size and relative complexity of sound category may play a role in determining production accuracy for both monolingual and bilingual children, although the order of acquisition plays a major role in determining phoneme production accuracy.

The current study provides clinical implications. First, when the bilingual children's phonological development is examined, bilingual researchers and speech pathologists should carefully examine the children's abilities in both languages that they are exposed to. Without fully understanding a bilingual child's abilities in both languages, accurate evaluation of their phonological development is a daunting task. Second, developmental psychologists and speech pathologists should be fully aware of the sound inventory of a child' $\mathrm{s}$ ambient language(s) to understand production accuracy comprehensively. If the inventory of a sound category (e.g., stops) is larger in one language, the expectation based on these findings is that the child might have lower accuracy for that category in that language.

Several limitations should be considered. Only 8 children per group participated. Although previous bilingual studies (e.g., Gildersleeve-Neumann et al., 2009; Fabiano-Smith \& Goldstein, 2010a, 
2010b) also examined a similar number of children, further studies should examine a larger cohort to validate these findings more broadly. Since KEB children in the current cohort showed similar language abilities except for a few participants, we did not subgroup them further. It would be interesting to examine if English-dominant, equally balanced, or Korean-dominant bilinguals demonstrate similar or different patterns in a larger cohort. Finally, the current study did not evaluate production accuracy based on word position. Production accuracy is different across word positions in Korean (Kim \& Pae, 2005). Further studies should carefully examine production accuracy at different position between monolingual and bilingual children.

In conclusion, overall the increasing population of bilingual and multilingual children both in the U.S. as well as in Korea suggests the importance of this type of study, which was designed to understand phonological development in bilingual children, a factor that may explain patterns of bilingual acquisition. Further studies may need to examine other bilingual language pairs (e.g., ChineseEnglish or Arabic-English) to confirm more generally our findings that the size and complexity of the sound category plays a role in production accuracy.

\section{Declaration of Conflicting Interests}

The author reports no conflict of interest.

\section{Acknowledgements}

This study was supported by the Eunice Kennedy Shriver National Institute of Child Health and Human Development (1R03HD061527A). The author would like to thank the children who participated in the study, the parents who gave their consent, and the childcare centers at which the data were collected. Especially, the author thanks Dr. Ja Hyung Lee at Ewha Women's University and Ms. Hwa-Sook Lee at the In-Wang Children's Center in Seoul, Korea, for their help with participant recruitment. Last, but not least, the author deeply appreciates student assistants for their help during data collection and analysis.

\section{REFERENCES}

Arlt, P. B., \& Goodban, M. T. (1976). A comparative study of articulation ac- quisition as based on a study of 240 normals, aged three to six. Language, Speech, and Hearing Services in Schools, 7(3), 173-180.

Bedore, L. M., Peña, E. D., Joyner, D., \& Macken, C. (2011). Parent and teacher rating of bilingual language proficiency and language development concerns. International Journal of Bilingual Education, 14(5), 489-511.

Bernthal, J. E., Bankson, N. W., \& Flipsen, P. (2009). Articulation and phonological disorders: speech sound disorders in children (6th Ed.). Boston, MA: Allyn \& Bacon.

Dodd, B., Holm, A., Zhu, H., \& Crosbie, S. (2003). Phonological development: a normative study of British English-speaking children. Clinical Linguistics « Phonetics, 17(8), 671-643.

Fabiano-Smith, L., \& Barlow, J. A. (2010). Interaction in bilingual phonological acquisition: evidence from phonetic inventories. International Journal of Bilingual Education and Bilingualism, 13(1), 81-97.

Fabiano-Smith, L., \& Goldstein, B. A. (2010a). Phonological acquisition in bilingual Spanish-English speaking children. Journal of Speech-LanguageHearing Research, 53(1), 160-178.

Fabiano-Smith, L., \& Goldstein, B. A. (2010b). Early-, middle-, and late-developing sounds in monolingual and bilingual children: an exploratory investigation. American Journal of Speech-Language Pathology, 19(1), 66-77.

Flege, J. E. (1989). Differences in inventory size affect the location but not the precision of tongue position in vowel production. Language and Speech, 32(2), 123-147.

Genesse, F. (1989). Early bilingual development: one language or two?. Journal of Child Language, 16(1), 161-179.

Gildersleeve-Neumann, C. E., Kester, E. S., Davis, B. L., \& Peña, E. D. (2008). English speech sound development in preschool-aged children from bilingual Spanish-English environments. Language, Speech and Hearing Services in Schools, 39(3), 314-328.

Gildersleeve-Neumann, C. E., Peña, E. D., Davis, B. L., \& Kester, E. S. (2009). Effects on L1 during early acquisition of L2: speech changes in Spanish at first English contact. Bilingualism: Language \& Cognition, 12(2), 259-272.

Goldman, R., \& Fristoe, M. (2000). Goldman-Fristoe Test of Articulation (2nd Ed.), Circle Pines, MN: American Guidance Service.

Goldstein, B. (2004). Bilingual Language Development \& Disorders in Spanish-English Speakers. Baltimore: Brookes Publishing Co.

Goldstein, B., \& Washington, P. (2001). An initial investigation of phonological patterns in 4-year-old typically developing Spanish-English bilingual children. Language, Speech, \& Hearing Services in the Schools, 32(3), 153164. 
Ha, S., Johnson, C. J., \& Kuehn, D. P. (2009). Characteristics of Korean phonology: review, tutorial, and case studies of Korean children speaking English. Journal of Communicative Disorders, 42(3), 163-179.

Hamers, J. F., \& Blanc, M. H. A. (2000). Bilinguality and Bilingualism. Cambridge: Cambridge University Press.

Holm, A., \& Dodd, B. (1999). A longitudinal study of the phonological development of two Cantonese-English bilingual children. Applied Psycholinguistics, 20(3), 349-376.

Heo, K., Squires, J., Lee, S., \& Lee, J. (2006). Korean Age and Stage Questionnaire (K-ASQ). Seoul: Seoul Community Rehabilitation Center.

Jun, J. A. (2014). A study of Teachers' Perception on Early Childhood English Education (Master's thesis). Chonnam National University, Gwangju, Korea.

Kang, S. J., \& Lee, Y. S. (2018). A study on social perception of early-childhood English education based on big data and social network analysis. Journal of Future early Childhood Education, 25(2), 141-168.

Kim, J. H., Ballard, E., \& McCann, C. (2017). Phonological skills in KoreanEnglish bilingual children: phonetic inventory and segmental accuracy. Clinical Archives of Communication disorders, 2(2), 142-162.

Kim, M. J., \& Pae, S. (2005). The percentage of consonants correct and the ages of consonantal acquisition for 'Korean-test of articulation for children (K-TAC)'. Speech Science, 12(2), 139-149.

Kim, M. J., Pae, S., \& Park, C. I. (2007). Assessment of phonology and articulation for children (APAC). Seoul: Human Brain.

Kim, M., \& Pae, S. (2007). Korean speech acquisition. In S. McLeod (Ed.), The international guide to speech acquisition (pp. 472-482). Clifton Park, NY: Thomson Delmar Learning.

Kim, M., \& Stoel-Gammon, C. (2009). The acquisition of Korean word-initial stops. Journal of Acoustical Society of America, 125, 3950-3961.

Kwon, K. (1982). Vowel acquisition and development. Annual Report of Korean Educational Development Institute, 16, 38-43.

Korean Statistics. (2019). Korean Social Trends 2019. Retrieved on June 28 , 2020 from file:///C:/Users/lab/Downloads/2019_02\%20\%EB\%8B\%A4\%E B\%AC\%B8\%ED\%99\%94\%EA\%B0\%80\%EC\%A0\%95\%20\%ED\%95\% 99\%EC\%83\%9D\%EC\%9D\%98\%20\%EC\%8B\%A4\%ED\%83\%9C\%20\% EB\%B0\%8F\%20\%EB\%B0\%9C\%EB\%8B\%AC\%20\%EC\%B6\%94\%EC\%9 D\%B4_050429.pdf.

Ladefoged, P., \& Maddieson, I. (1996). The sounds of the world's languages. Oxford, UK: Blackwell Publishers.

Larkins, P. (1983). Development at 4 years. In J. V. Irwin \& S. P. Wang (Eds.),
Phonological development in children: 18-72 months (pp. 107-132). Carbondale: Southern Illinois University Press.

Lin, L. C., \& Johnson, C. J. (2010). Phonological patterns in Mandarin-English bilingual children. Clinical Linguistics \& Phonetics, 24(4-5), 369-386.

Lindblom, B. (1983). Economy of speech gestures. In P. MacNeilage (Ed.), The production of speech (pp. 217-246). New York: Springer.

Lindblom, B., \& Maddieson, I. (1988). Phonetic universals in consonant system. In C. Li \& L. M. Hyman (Eds.), Language, speech and mind (pp. 6278). Routledge: London.

Lindblom, B., \& Sundberg, J. (1971). Acoustical consequences of lip, tongue, jaw and larynx movement. Journal of Acoustical Society of America, 50(4B), 1166-1179.

McHugh, M. A. (2012). Interrater reliability: the kappa statistic. Biochemia Media, 22(3), 276-282.

McLeod, S. (2007). The international guide to speech acquisition. Clifton Park, NY: Thomson Delmar Learning.

Nettle, D. (1995). Segmental inventory size, word length, and communicative efficiency. Linguistics, 33(2), 359-367.

Oller, D. K., \& Delgado, R. E. (1990). Logical International Phonetics Programs. [Computer software]. Miami, FL: Intelligent Hearing Systems.

Otomo, K., \& Stoel-Gammon, C. (1992). The acquisition of unrounded vowels in English. Journal of Speech and Hearing Research, 35(3), 604-616.

Padilla, A., \& Lindholm, K. (1984). Child bilingualism: the same old issues revisited. In J. L. Martinez \& R. H. Mendoza (Eds.), Chicano Psychology (2nd ed., pp. 369-408). New York: Academic Press.

Paradis, J., \& Genesee, F. (1996). Syntactic acquisition in bilingual children: autonomous or interdependent?. Studies in Second Language Acquisition, 18(1), 1-25.

Pollock, K. E. (2002). Identification of vowel errors: methodological issues and preliminary data from the Memphis Vowel Project. In M. J. Ball \& F. E. Gibbon (Eds.), Vowel disorders (pp. 83-113). Boston, MA: Butterworth Heinemann.

Pollock, K. E., \& Berni, M. C. (2003). Incidence of non-rhotic vowel errors in children: data from the Memphis vowel project. Clinical Linguistics \& Phonetics, 17(4-5), 393-401.

Rvachew, S., \& Brousseau-Lapre, F. (2012). Developmental and phonological disorders. San Diego, CA: Plural.

Smit, A. B., Hand, L., Freilinger, J. J., Bernthal, J. E., \& Bird, A. (1990). The Iowa articulation norms project and its Nebraska replication. Journal of Speech and Hearing Disorders, 55(4), 779-798. 
Sue Ann S. Lee • Consonant and Vowel Production Accuracy in Korean-English Bilinguals

U.S. Bureau of the Census. (2010). Statistical abstract of the United States. Washington, DC: US Department of Commerce.

Volterra, V., \& Taeschner, T. (1978). The acquisition and the development of language by bilingual children. Journal of Child Language 5(2), 311-326.

Zimmerman, I. L., Steiner, V. G., Pond, R. E. (2005). Preschool Language Scale-4 Screening Test. San Antonio, TX: Psychological Corporation. 


\section{국문초록}

\section{한국어/영어 이중언어 아동의 한국어 영어 자음및 모음 발화의 정확성}

\section{Sue Ann S. Lee}

Texas Tech University Health Sciences Center, USA

배경 및 목적: 이중언어를 사용하는 아동의 음소발달연구는 주로 영어를 포함한 인도유럽어에 치중되어 왔으며 한국어와 영어를 같 이 사용하는 이중언어 아동의 음소발달연구는 매우 제한적으로 이루어져왔다. 따라서 본 연구는 한국어/영어 이중언어 아동이 발화 하는 한국어 및 영어 자음과 모음의 정확도가 단일언어를 사용하는 미국 또는 한국아동과 비교하여 차이가 있는지 알아보고자 하였 다. 방법: 3 세의 이중언어 아동 중 18 개월 이전에 한국어와 영어를 동시에 습득한 아동을 대상으로 표집하였다. 그림 어휘검사를 이용 하여 이중언어 아동 8 명, 영어 단일언어 아동 8 명, 한국어 단일언어 아동 8 명(총 24 명)의 한국어, 영어 자음과 모음 정확도를 측정하였다. 결과: 이중언어 아동의 영어 자음과 모음의 정확도는 영어를 단일어로 사용하는 미국 아동과 비교하여 유의한 차이를 나타내지 않았 다. 그러나 한국어의 자음과 모음의 정확도는 한국 아동에 비해 유의하게 낮았다. 한국어와 영어의 정확도를 비교했을때 이중언어 집 단과 단일언어 집단에서 모두 영어의 파열음과 파열파찰음의 정확도가 한국어의 파열음과 파열마찰음의 정확도보다 유의하게 높았 다. 논의 및 결론: 이중언어 아동의 음소 정확성은 어떤 언어가 좀더 지배적인 언어인가 또는 사용 언어가 얼마나 유창한가 관련되어 있 는 것으로 보인다. 또한 언어의 음소 크기나 복잡성이 아동의 음소 발화의 정확도에 영향을 미치는 것으로 여겨지나, 이러한 요인은 아 동의 음소발달과의 관계에서 이해되어져야 할 것이다.

핵심어: 음소 정확성, 음소크기와 복잡성, 음소발달, 한국어-영어 이중언어, 이중언어동시습득

본 연구는 미국 국립보건원(Eunice Kennedy Shriver National Institute of Child Health and Human Development)의 연구비 지원으로 이루 어졌음(1R03HD061527A).

\section{참고문헌}

강승지, 이연선(2018). 우리나라 유아 영어교육에 대한 사회적 인식 연구: 빅데이터와 사회연결망 분석을 중심으로. 미래유아교육학회지, 25(2), 141168.

김민정, 배소영(2005). 아동용 조음검사를 이용한 연령별 자음정확도와 우리말 자음의 습득연령. 음성과학, 12(2), 139-149.

김민정, 배소영, 박창일(2007). 아동용 조음검사. 휴브 알엔씨.

전주아(2014). 유아영어교육에 대한 유아교사와 유아영어교사의 인식연구: 광주 전남지역 어린이집을 중심으로. 전남대학교 대학원 석사학위논문. 허계형, Jane Squires, 이소영, 이준석(2006). K-ASQ: 부모작성형 유아모니터링 체계. 서울재활센터.

\section{ORCID}

Sue Ann S. Lee (제1저자, 교신저자, 부교수 https://orcid.org/0000-0002-2970-0591) 